\title{
CELL DECOMPOSITION AND CLASSIFICATION OF DEFINABLE SETS IN $p$-OPTIMAL FIELDS - CORRIGENDUM
}

\author{
LUCK DARNIÈRE AND IMMANUEL HALUPCZOK
}

In the paper by Darnière and Halupczok [1], the second author's name appeared incorrectly as "Immanuel Halpuczok".

The author's name should appear as Immanuel Halupczok.

This has been corrected in the original article.

\section{REFERENCE}

[1] L. DARNièRE and I. HALUPCZOK, Cell decomposition and classification of definable sets in p-optimal sets, this JournaL, vol. 82 (2017), no. 1, pp. 120-136. DOI:10.1017/js1.2015.79. 